(2) Open Access Full Text Article

REVIEW

\title{
Female genital mutilation and male circumcision: toward an autonomy-based ethical framework
}

This article was published in the following Dove Press journal:

Medicolegal and Bioethics

3 October 2015

Number of times this article has been viewed

\section{Brian D Earp}

Department of History and Philosophy of Science, University of Cambridge, Cambridge, UK

\begin{abstract}
The non-therapeutic alteration of children's genitals is typically discussed in two separate ethical discourses: one for girls, in which such alteration is conventionally referred to as "female genital mutilation" (or FGM), and one for boys, in which it is conventionally referred to as "male circumcision." The former is typically regarded as objectionable or even barbaric; the latter, benign or beneficial. In this paper, however, I call into question the moral and empirical basis for such a distinction, and I argue that it is untenable. As an alternative, I propose an ethical framework for evaluating such alterations that is based upon considerations of bodily autonomy and informed consent, rather than sex or gender.
\end{abstract}

Keywords: FGM, circumcision, gender, sexuality, autonomy, consent

"The cutting of healthy genital organs for non-medical reasons is at its essence a basic violation of girls' and women's right to physical integrity. This is true regardless of the degree of cutting or the extent of the complications that may or may not ensue."

- Anika Rahman and Nahid Toubia

"Most illogical is the use of the term 'male genital mutilation' to refer to male circumci-

sion ... in an attempt to equate the latter with female genital mutilation, with which it has little in common, either anatomically or health-wise."

-Brian J Morris ${ }^{2}$

\section{Introduction}

The non-therapeutic surgical alteration of children's genitals is treated very differently in Western societies, depending upon the sex or gender ${ }^{\mathrm{a}}$ of the child whose genitals are altered. When such alteration is done to females, it is often branded "female genital mutilation" (or FGM) and is typically deemed to be wholly impermissible. FGM is illegal in many developed countries, is punishable by lengthy prison sentences and/or hefty fines, ${ }^{9}$ and is proscribed by the United Nations. ${ }^{10,11}$ When such alteration is done to males, by contrast, it is usually given the label "male circumcision" - and is conventionally regarded as being benign or beneficial. ${ }^{12}$ In almost no jurisdiction is such

${ }^{a}$ The relationship between sex and gender, as well as how each should be defined, is notoriously complex; ${ }^{3}$ I will not be able to explore that thicket in this essay. In a similar vein, although the genital alteration of so-called intersex individuals has drawn considerable critical attention, ${ }^{4-7} \mathrm{I}$ will have to set aside that issue as well. For a hint of my views, however, see the essay by Carmack, Notini, and Earp (in press). ${ }^{8}$ 
alteration prohibited (in many it is not even regulated); ${ }^{13,14}$ and in some it is actively promoted, for example, as a form of partial prophylaxis against certain diseases. ${ }^{b}$

Why such divergent treatment? As one prominent ethicist has noted, "these two practices, dramatically separated in the public imagination, actually have significant areas of overlap." ${ }^{21}$ For example, both types of intervention involve the incision (and usually, though not always, the excision) of healthy, erogenous tissue. ${ }^{11,22,23}$ Both concern an individual's "private parts," yet are done without the person's own consent. And neither involves the treatment of disease, nor the correction of an acknowledged deformity. ${ }^{24}$ Prima facie, then, at least according to this way of thinking, a similar medical-ethical analysis - based on conventional bioethical principles - would seem to apply to both.

Yet this is not the predominant opinion expressed in Western popular discourse, nor in much of the scholarly literature. In these domains, as well as in many others, the two types of intervention are rarely discussed in the same context..$^{25}$ Moreover, when they are characterized as being potentially comparable, the reaction is often incredulous. For example, when the anthropologist Kirsten Bell put forward such a comparison in her university lectures, the response from her students was "immediate and hostile":

"How dare I mention these two entirely different operations in the same breath! How dare I compare the innocuous and beneficial removal of the foreskin with the extreme mutilations enacted against females in other societies!"²6

One recurrent claim is that FGM is analogous to "castration" or a "total penectomy," such that any sort of comparison between it and male circumcision is entirely inappropriate. ${ }^{27}$ This perspective alludes to a harm-based argument for the (distinctive) impermissibility of female forms of genital alteration. On this sort of view, the sheer level of harm entailed by FGM passes a threshold of intolerability that is not passed by male circumcision. FGM is also seen as lacking in any benefit (as the World Health Organization states: FGM has "no health benefits, [and] only [causes] harm"), ${ }^{28}$ whereas potential health-based benefits are not infrequently raised in support of male circumcision. ${ }^{29-30}$

${ }^{\mathrm{b}}$ Such promotion is largely driven by a core group of (primarily) US-based researchers ${ }^{15}$ who have succeeded in influencing the policies of not only of the American Academy of Pediatrics ${ }^{16}$ and the US Centers for Disease Control and Prevention, ${ }^{17,18}$ but also the World Health Organization. ${ }^{19}$ For further analysis of the health benefits arguments in favor of male circumcision, see my essay, "Do the Benefits of Male Circumcision Outweigh the Risks? A Critique of the Proposed CDC Guidelines" in the journal Frontiers in Pediatrics. ${ }^{20}$ See also the relevant sections below.
In the first section of this essay, I call into question the claims upon which these distinctions are typically premised. Specifically, I show that at least certain forms of FGM (or female genital alteration $[\mathrm{FGA}],{ }^{21}$ including forms that are legally prohibited in Western societies, are demonstrably less harmful than the most prevalent forms of male circumcision. I also show that certain forms of male circumcision (or male genital alteration [MGA]), including forms that are common in parts of Africa and elsewhere, can be at least as harmful as the most extreme forms of FGA as practiced in any context. I will also question the claims that have been made on the point of health benefits, with respect to both types of genital alteration.

The harm-based argument, then, does not turn out to be sufficient to draw a strict moral distinction between male and female forms of genital cutting practices. The consequence of this conclusion can be stated as a conditional: if the degree of harm vs benefit commonly attributed to male circumcision is seen as being compatible with its permissibility in Western societies, then forms of female genital cutting that result in a similar degree of harm vs benefit must also be considered permissible on these grounds. ${ }^{c}$ Yet many would resist this conclusion. Indeed, the official position of such influential bodies as the World Health Organization and the United Nations is that any kind of medically unnecessary, non-consensual alteration of the female genitalia - no matter how minor the incision, no matter what type of tissue is or is not removed, no matter how slim the degree of risk, and no matter how sterile the equipment used - is by definition an impermissible "mutilation."11

Granting this view for now (although it is not uncontroversial), ${ }^{11,21}$ perhaps we can find some other moral basis on which to ground a gender or sex-based distinction. The philosopher Joseph Mazor has recently advanced an intuitive-sounding possibility:

There is an important moral difference [between male and female forms of genital alteration] that does not have to do with the physical effects of the operation[s]. Namely, in some ... of the cultures in which female genital cutting is practiced, the practice reflects deeply-rooted attitudes about the lower status of women. Thus, even if male and female genital cutting were perfectly identical in terms of net health benefits and effects on sexual pleasure, the

cAnd conversely, if the degree of net harm commonly attributed to FGA is seen as being incompatible with its permissibility in Western societies, then forms of MGA that result in a similar (or greater) degree of net harm must also be considered impermissible on these grounds. 
relationship in some cultures between female genital cutting and a failure to respect women as moral equals would give an additional reason to object to female circumcision. ${ }^{31}$ (emphasis added)

This line of thought, which I will refer to as the "symbolic meanings" argument, will be the focus of the second section of my paper. In this section, I argue that Mazor's proposed distinction, while potentially appealing on a first-pass assessment, is ultimately untenable. First, as Mazor himself concedes, male and female forms of genital alteration are carried out for different reasons, and reflect different norms and attitudes, in different cultural contexts. In some cases, the "symbolic meanings" of these respective alterations are in fact quite similar. Indeed, contrary to common wisdom, non-therapeutic FGA is not always associated with, nor a reflection of, sexist and patriarchal norms; nor are the norms associated with male genital cutting always as morally innocent as is typically assumed.

Accordingly, even if one were to grant that the moral permissibility of each type of genital cutting - stipulated to be equally (physically) harmful for the sake of this analysis hinged on the attitudes or norms that they "reflected," it would still be necessary to distinguish between such attitudes and norms on a context-specific basis, and possibly even caseby-case. Apart from the practical difficulties that would be incurred by such a task, there are a number of epistemological difficulties as well.

As I conclude, therefore, the Western habit of drawing a stark moral distinction between male and female forms of non-therapeutic, non-consensual genital alteration may be impossible to maintain on principled grounds - or if not impossible, certainly much more difficult than is commonly assumed. In the final section of this paper, I provide a very brief sketch of an ethical framework that could be used to evaluate such alterations in a more consistent and principled way. Instead of being based on considerations of sex or gender, my proposed framework will be based on considerations of bodily autonomy and informed consent.

\section{Male and female forms of genital alteration: the question of harm}

That FGA is harmful to women and girls - and certainly much more harmful than MGA - is a truism in Western societies. This is the harm-based argument to which I alluded earlier, and I have already suggested that it cannot succeed. To see why this is the case, it is necessary to begin with a widelyaccepted definition of FGM (if I may now revert to the conventional terminology for the sake of this discussion) so that we can understand what is at stake in such a procedure, followed by an analysis of male circumcision. The World Health Organization gives us the following typology: ${ }^{32}$

FGM Type 1 - This refers to the partial or total removal of the clitoral glans (the part of the clitoris that is visible to the naked eye) and/or the clitoral prepuce ("hood"). This is sometimes called a "clitoridectomy," 28 although such a designation is misleading: the external clitoral glans is not always removed in this type of FGM, and in some versions of the procedure-such as with so-called "hoodectomies"-it is deliberately left untouched..$^{33}$ There are two major sub-types. Type 1(a) is the partial or total removal of just the clitoral prepuce (ie, the fold of skin that covers the clitoral glans, much as the penile prepuce covers the penile glans in boys; in fact, the two structures are embryonically homologous). ${ }^{34 \mathrm{~d}}$ Type 1(b) is the same as Type 1(a), but includes the partial or total removal of the external clitoral glans. Note that two-thirds or more of the entire clitoris (including most of its erectile tissue) is internal to the body envelope, ${ }^{35}$ and is therefore not removed by this type, or any type, of FGM.

FGM Type 2 - This refers to the partial or total removal of the external clitoral glans and/or the clitoral hood (in the senses described above), and/or the labia minora, with or without removal of the labia majora. This form of FGM is sometimes termed "excision." Type 2(a) is the "trimming" or removal of the labia minora only; this is also known as labiaplasty when it is performed in a Western context by a professional surgeon (in which case it is usually intended as a form of cosmetic "enhancement"). ${ }^{33}$ In this context, such an intervention is not typically regarded as being a form of "mutilation," even though it formally fits the WHO definition. Moreover, even though such "enhancement" is most often carried out on consenting adult women in this cultural context, it is also sometimes performed on minors, apparently with the permission of their parents. ${ }^{11,36}$ There are two further subtypes of FGM Type 2, involving combinations of the above interventions.

FGM Type 3 - This refers to a narrowing of the vaginal orifice with the creation of a seal by cutting and repositioning the labia minora and/or the labia majora, with or without excision of the external clitoris. This is the most extreme type of FGM, although it is also one of the rarest, occurring

${ }^{\mathrm{d}}$ Note that, on some interpretations, FGM Type 1(a) is the strict anatomical equivalent of male circumcision, since both procedures constitute the removal of the genital prepuce. However, such comparisons are not quite exact: in the male version of the procedure, many more square centimeters of erogenous tissue are removed due to the larger size of the penile prepuce. 
in approximately $10 \%$ of cases. ${ }^{11,37}$ When the "seal" is left in place, there is only a very small hole to allow for the passage of urine and menstrual blood, and sexual intercourse is rendered essentially impossible. This type of FGM is commonly called "infibulation" or "pharaonic circumcision" and has two additional subtypes.

FGM Type 4 - This refers to "all other harmful procedures to the female genitalia for non-medical purposes" and includes such interventions as pricking, nicking, piercing, stretching, scraping, and cauterization. ${ }^{32}$ Counterintuitively for this final category - which one might expect to be even "worse" than the ones before it - several of the interventions just mentioned are among the least severe forms of FGM. Piercing, for example, is another instance of a procedure - along with labiaplasty (FGM Type 2) and "clitoral unhooding" ${ }^{33}$ (FGM Type 1) - that is popular in Western countries for "non-medical purposes," and can be performed hygienically under appropriate conditions. ${ }^{11,38-40}$

\section{The harms of FGM/A}

Several points can now be emphasized. First, "FGM" is not just one thing. Instead, there are many ways to nick, scratch, or cut off parts of a girl's vulva, ranging from (at the lowest end of the harm spectrum) an anaesthetized prick on the clitoral hood, as is common in Malaysia and in some other Muslim communities, ${ }^{11,41}$ to (at the highest end of the spectrum) the excision of the outer clitoris with a shard of glass, and the suturing of the labia with thorns. ${ }^{42}$ It should be clear that these different forms of intervention are likely to result in different degrees of harm, with different effects on sexual function and satisfaction, different chances of developing an infection, and so on, among the other possible adverse consequences that may be associated with these procedures. ${ }^{43}$ But as Carla Obermeyer has observed:

It is rarely pointed out that the frequency and severity of complications are a function of the extent and circumstances of the operation, and it is not usually recognized that much of [our] information comes from studies of the Sudan, where most women, [in contrast to the majority of other contexts] are infibulated. The ill-health and death that these practices are thought to cause are difficult to reconcile with the reality of their persistence in so many societies, and raises the question of a possible discrepancy between our "knowledge" of their harmful effects and the behavior of millions of women and their families. ${ }^{44}$

A further point to consider is that many of the risks and harms that are associated with FGM - such as pain, infection, and hemorrhage - could be substantially reduced, if not eliminated, by transitioning toward the less invasive forms of the procedure, coupled with an increased focus on "medicalization. ${ }^{, 45,46}$ In light of this recognition, more minor forms of female genital alteration are indeed being performed in hospital settings in an increasing number of communities worldwide, on the model of routine male circumcision as performed in the United States. ${ }^{47}$ This trend has not been welcomed, however, by those who oppose FGM regardless of implementation or type, ${ }^{11,47,48}$ and it has been explicitly condemned by both the World Health Organization and the United Nations. ${ }^{11}$

What about effects on sexuality? ${ }^{44}$ While a popular assumption is that any form of FGM deprives women of all sexual feeling, "[r]esearch by gynecologists and others has demonstrated that a high percentage of women who have had genital surgery have rich sexual lives, including desire, arousal, orgasm, and satisfaction, and their frequency of sexual activity is not reduced." ${ }^{, 49}$ Indeed, in one study, ${ }^{50}$ up to $86 \%$ of women-some of whom had undergone even "extreme" forms of FGM-reported the ability to orgasm, and "the majority of the interviewed women (90.51\%) reported that sex gives them pleasure." These counterintuitive findings might be explained by the fact, noted earlier, that much of the clitoris is actually underneath the skin layer and is therefore not removed by even the most invasive types of FGM. ${ }^{e}$ Of course, there are other parts of the vulva/vagina to consider as well, whose stimulation can likewise contribute to sexual pleasure. All told, the degree and quality of subjective sexual feeling is likely to vary considerably depending upon the type of FGM, as well as from person to person: the number and distribution of nerve endings, etc - and hence the sexual responsiveness of each person's genitals - is unique. Therefore FGM and other forms of genital modification will affect different people differently. ${ }^{51}$

On the other side of the ledger, there is a great deal of evidence ${ }^{f}$ that FGM can be harmful to sexual function

\footnotetext{
${ }^{\mathrm{e}} \mathrm{As}$ Catania et al. report: "It is ... important to remember that in infibulated women, some fundamental structures for the orgasm have not been excised. The women interviewed by [some researchers] achieve orgasm by stimulating the vagina and consider the clitoris as something extra. In reality they refer to the visible (external) part of the clitoris which is [only] the "tip of the iceberg' of the whole structure, strictly connected to the vagina." ${ }^{50}$ ${ }^{\mathrm{f}} \mathrm{However}$, see Obermeyer ${ }^{55}$ for an important discussion of the methodological difficulties inherent in these types of studies, as well as the need to distinguish between more vs less invasive forms of FGM/A when reporting on its effects on sexuality. See also, eg, Meston et al. ${ }^{56}$ for evidence of a lack of ability to orgasm among some women with intact genitalia, further complicating the relationship between ability-to-orgasm and the presence or absence of an external clitoral glans.
} 
and experience, especially when one considers the more extreme forms. ${ }^{52-54}$ Women in some studies have reported feeling "cold" during sex, deriving "no satisfaction" from intercourse, and "having pain during sex." ${ }^{" 57}$ As Sara Johnsdotter has pointed out, ${ }^{51}$ the relationship between the amount of genital tissue removed from any individual and her felt satisfaction during sexual intercourse is complex (as well as difficult to study in a controlled, scientific manner), so FGM-of whatever degree of severity-will lead to different psychologically-mediated outcomes, depending upon the beliefs, attitudes, and other internal states of the affected individual. ${ }^{50,51}$ As I have argued elsewhere:

While many African women feel enhanced by having modified genitals - feeling more beautiful, 'cleaner,' more 'smooth' and 'neat' - increasing numbers of them are aware of just how controversial their local customs have become on the world stage. Many of them are learning about how other cultures and societies regard the innervation and functions of the clitoris. Some of them are dating outside of their cultural groups [and finding] out that 'cut' genitals are not considered beautiful by the prevailing group in such contexts, and so on. Accordingly, they may feel humiliated, deprived, diminished - and yes, 'mutilated.' There is even [some] evidence of women seeking reconstructive surgery of their genitals to try to reclaim what was 'taken from them' when they were too young to fully understand what was happening. ${ }^{11}$

In the final analysis, it is clear that FGM, and especially its more invasive forms, poses a distinct risk of causing sexual harm, even if this harm may not be experienced in the same way, or to the same degree, by every woman who has been subjected to genital surgery. Moreover, in at least some cases, the harm is quite clearly catastrophic.

\section{The harms of MGA}

These same considerations apply to male circumcision. As with FGM/A, circumcision is not a monolith: it isn't just one kind of thing. ${ }^{\mathrm{g}}$ The original form of circumcision within Judaism, for example, until about 150 AD, was comparatively minor: it involved cutting off the overhanging tip of the foreskin - whatever stretched out over the end of the glans - thus preserving (most of) the foreskin's protective and motile functions, as well as limiting the amount of erogenous tissue removed. ${ }^{58}$ The "modern" form adopted by the United States $^{59}$ is significantly more invasive: it typically removes

${ }^{\mathrm{g}}$ For a proposed typology, see Svoboda and Darby. ${ }^{25}$ between one-third to one-half of the movable skin system of the penis, ${ }^{60}$ or about 50 square centimeters of sensitive tissue in the adult organ. ${ }^{61,62}$ The operation also eliminates the gliding function of the prepuce (which may help to reduce chafing in the female sexual partner), ${ }^{\mathrm{h}}$ as well as any and all sexual sensation in the prepuce itself; ${ }^{23,62}$ and it exposes the head of the penis to environmental irritation. ${ }^{23,60}$ Just as with various forms of non-therapeutic FGA, male circumcision has been associated with numerous sexual difficulties, ranging from reduced sensitivity in the exposed glans, to problems with orgasm, to pain in the receptive female partner. ${ }^{64-66}$ Nevertheless, many, if not most, circumcised men report being able to enjoy their sexual experiences, notwithstanding the loss of erotogenic tissue $^{67,68}$ (see Box 1 for further discussion).

Just as with FGA, male genital cutting can take many different forms. In Pakistan, traditional Muslim circumcisions are done while the boy is fully conscious, usually between the ages of 3 and 7. As S A Rizvi and colleagues describe, "the child is held in a seated position, with both legs apart." Then, "a probe, a cutter made of wood, and a razor are used [to excise] the prepuce," at which point "ashes of burnt wood are [applied] to establish haemostasis." 72 The operation is performed "with no anaesthesia, no sutures and with unsterilized instruments." 72 In the United States, routine (non-religious) circumcisions are performed in a hospital setting, and take place in the first few days of life. These, too, often involve inadequate (or no) pain control, and have been known to result in serious "botches," including partial amputations of the penis. While such an outcome is typically described as "rare," the true incidence of complications is unknown. ${ }^{13,16,73}$ Metzitzah b'peh, done by some ultra-Orthodox Jews, requires the sucking of blood from the circumcision wound, and carries the risk of herpes infection and permanent brain damage. ${ }^{74}$ Subincision, performed by some Australian aboriginal groups, involves slicing open the urethral passage on the underside of the penis from the scrotum to the glans, often affecting urination as well as sexual function. ${ }^{75,76}$ As Derrick J Pounder states, "the bleeding is staunched with sand, and the edges of the wound may be cauterized ... the resultant defect in the urethral wall is kept open [with] pieces of wood, bone,

${ }^{\text {h}}$ As Scott states: "Upon full erection, there is ample play in the penile skin to allow the glans to glide in and out of the prepuce. During the inward motion of intercourse, the ridged mucosa, positioned now near the mid-penile shaft, glides along and in contact with the vaginal wall. The Meissner's corpuscles [sensitive nerve fibers] in the crests of the ridged mucosa are stimulated by this contact and by the restraint of the frenulum, with which the ridged mucosa is continuous. In the outward motion of intercourse, the prepuce inverts over the distal portion of the penis. The Meissner's corpuscles are again stimulated, this time by contact with the corona glandis." ${ }^{63}$ 
The literature concerning the sexual effects of male circumcision is hotly contested. ${ }^{69,70}$ However, the most recent, comprehensive, and balanced review of the available evidence is due to Jennifer Bossio and her colleagues, ${ }^{68}$ who note that: "Adverse self-reported outcomes associated with foreskin removal in adulthood include impaired erectile functioning, orgasm difficulties, decreased masturbatory functioning (loss in pleasure and increase in difficulty), an increase in penile pain, a loss of penile sensitivity with age, and lower subjective ratings of penile sensitivity" (internal references omitted). ${ }^{68}$ While "other studies have found no significant differences in self-reported sexual functioning following adult circumcision," it must be remembered that (a) adult vs infant/child circumcision may not necessarily yield equivalent outcomes, ${ }^{23}$ and (b) that a lack of statistical significance does not entail a lack of underlying effect. ${ }^{71}$ For example, in an oft-cited study purporting to show no adverse effect of circumcision on sexuality, "several questions were too vague to capture possible differences between circumcised and not-yet circumcised participants [such that] non-differential misclassification of sexual [outcomes] probably favored the null hypothesis of no difference, whether an association was truly present or not." ${ }^{66}$ Finally, due to the fact the foreskin "can be stretched, rolled back and forth over the glans, and otherwise manipulated during sex and foreplay, [allowing] for a range of sexual functions - along with their concomitant sensations - that are physiologically impossible if this tissue is removed ... To say that circumcision has 'little or no effect' on sexual experience [is] to adopt an extremely narrow conception of that term" ${ }^{23}$

Box I - What are the effects of male circumcision on sexual function, satisfaction, and sensation?

or clay." 75 Circumcision among the Xhosa in South Africa is traditionally done in the bush as a rite of passage, sometimes with the use of spearheads and dirty knives, and frequently by medically untrained practitioners. Just as with female genital altering rites performed under comparable conditions (and often by the very same groups), these kinds of operations frequently cause hemorrhage, infection, mangling, and loss of the sexual organ. ${ }^{77}$ In fact, between 2008 and 2014, more than half a million boys were hospitalized due to botched circumcisions in South Africa alone; more than 400 lost their lives. ${ }^{78,79}$ But even when performed in a modern clinical setting, circumcisions are not without their risks and complications. In 2011, nearly a dozen infant boys were treated for "life threatening hemorrhage, shock or sepsis" as a result of their non-therapeutic circumcisions at a single children's hospital in Birmingham, England. ${ }^{80}$

By now it should be clear, as Debra DeLaet (among others) has argued, ${ }^{81, i}$ that both male and female forms of genital alteration fall on a wide spectrum, and that the harms they may entail substantially overlap..$^{21}$ That this is not commonly understood in the popular discourse is most likely due to the fact that when Westerners hear the term "FGM," they tend to think of the most extreme forms of female genital cutting, done in the least sterilized environments, with the most drastic consequences likeliest to follow (since these are the forms to which they will typically have been exposed, due

${ }^{\mathrm{i}}$ As she writes, while "there are sharp differences between infibulation, the most extreme form ... of female genital mutilation, and the less invasive form of male circumcision that is most widely practiced ... that comparison is not necessarily the most appropriate comparison that can be made. There are extremely invasive forms of male circumcision that are as harsh as infibulation [and while it] is true that these extreme forms of male circumcision are rare ... it is also the case that infibulation [is rare]. Indeed, female circumcision as it is commonly practiced can be as limited in terms of the procedures that are performed and their effects as the most widespread type of male circumcision." ${ }^{81}$ to their disproportionate representation in the media and in other popular accounts).$^{49}$ When people hear the term "male circumcision," by contrast, they are much more likely to think of the least severe forms of male genital cutting, done in the most sterilized environments, with the least drastic consequences likeliest to follow, largely because this is the form with which they are culturally familiar. ${ }^{11,82}$

However, as the anthropologist Zachary Androus has noted, this way of thinking is misleading: "The fact of the matter is that what's done to some girls [in some cultures] is worse than what's done to some boys, and what's done to some boys [in some cultures] is worse than what's done to some girls. By collapsing all of the many different types of procedures performed into a single set for each sex, categories are created that do not accurately describe any situation that actually occurs anywhere in the world." ${ }^{.83}$

\section{The other side of the coin: the question of benefits}

So far, I have discussed the potential harms of male and female genital alterations, but I have not yet considered the question of benefits. MGA, but not FGA, is believed by some medical professionals to confer a number of possible health benefits ${ }^{\mathrm{j}}$ - most notably, a small reduction in the absolute risk of female-to-male, heterosexually transmitted HIV in areas with high base rates of such infection ${ }^{16-19,84}$ - although

${ }^{\mathrm{j}}$ For an overview of the scientific and ethical controversy surrounding the question of health benefits in a Western context, see my earlier work on the subject; ${ }^{20,85}$ for critiques of US-based support for circumcision specifically, see, eg, Frisch et al., ${ }^{86}$ Svoboda and Van Howe ${ }^{87}$ Garber $;{ }^{88}$ Hartmann, ${ }^{89}$ Lawson; $;{ }^{90}$ Booker; ${ }^{91}$ Bewley and Stranjord; ${ }^{92}$ Guest; ${ }^{93}$ Androus; $; 4$ Earp and Darby; ${ }^{62}$ Earp; ${ }^{95}$ and Bossio et al. ${ }^{68}$ Note that replies and counter-replies to some of these critiques have been published; these can be accessed at the relevant journal websites. 
the likelihood and the magnitude of such benefits outside of sub-Saharan Africa is the subject of considerable dispute. If these authorities are correct, then the benefits of circumcision might conceivably offset the drawbacks and risks in a way that is not the case for FGA, thereby preserving the moral distinction between them.

An important qualification is in order. First, almost all of the controlled evidence pointing to potential health benefits for MGA has been derived from studies of adult (and hence voluntary) circumcision, rather than from infant/child (and hence involuntary) circumcision. ${ }^{68}$ Since "the spread of disease, including sexually transmitted infections, is determined much more by socio-behavioral and situational factors than by strictly anatomical-biological factors, such as the presence or absence of a foreskin ... the apparent findings from these studies cannot be simply mapped on [to] circumcisions performed earlier in life, ie, before an age of sexual debut." ${ }^{20}$ This distinction is important. From an ethical perspective, few people would argue that fully-informed adult males should not be permitted to undergo elective surgeries on their own genitals, whether in an attempt to achieve partial prophylaxis against disease or for other reasons. This issue of informed consent will feature prominently in our discussion later on.

With respect to neonatal or childhood circumcision, by contrast, the primary health benefit that has been attributed to this version of the surgery is a slight reduction in the absolute risk of urinary tract infections. ${ }^{86}$ However, the overall chance of contracting such an infection (in the first year of life) is low-approximately 1\%-regardless of one's circumcision status. ${ }^{96}$ As Benatar and Benatar explain, "UTI does not occur in $99.85 \%$ of circumcised infant males and in $98.5 \%$ of uncircumcised infant boys. ${ }^{\prime 97}$ In the rare event that a child does in fact become infected, UTIs are both "easily diagnosed and treatable, with low morbidity and mortality." 97 A further point to consider is that: according to one recent estimate, about 111 circumcisions would have to be performed to prevent a single case of UTI. ${ }^{98}$ Accordingly, "a more conservative, humane, and effective course of treatment would be to prescribe oral antibiotics - if and when an infection does occur. This is just what we do for girls, who get UTIs (after the age of 1) about 10 times more frequently than boys do, with no pre-emptive surgery recommended." ${ }^{\prime \prime 2}$

But what if such surgery were recommended? The question cannot be left unanswered. The point here is that we do not actually know whether some minor form of FGA might confer health benefits, because it is illegal - and would be unethical $1^{23,43}$ - to conduct a study to find this out. Obviously, the more extreme types of FGA will not contribute to good health on balance, but neither will the spearheads-and-dirtyknives versions of MGA performed on boys. What about more mild forms of FGA? As I have noted elsewhere, "the vulva has all sorts of warm, moist places where bacteria or viruses could get trapped, such as underneath the clitoral hood, or among the folds of the labia; so who is to say that removing some of that tissue (with a sterile surgical tool) might not reduce the risk of various diseases?" 82

As a matter of fact, defenders of FGA in some countries actually do cite such "health benefits" as "a lower risk of vaginal cancer ... less nervous anxiety, fewer infections from microbes gathering under the hood of the clitoris, and protection against herpes and genital ulcers." 25 Moreover, at least one study by Western scientists has shown a link between "female circumcision" and reduced transmission of HIV - a result that the authors, both experienced statisticians, characterized as a "significant and perplexing inverse association between reported female circumcision and HIV seropositivity." ${ }^{99,100}$ The authors, Rebecca Stallings and Emilian Karugendo, expressed a dire need for further research into the issue. Yet as the medical anthropologist Kirsten Bell has noted (personal communication, January 16, 2015):

These findings, which were presented at an International AIDS Society conference in 2005 , have never been published in a peer-reviewed journal and it is difficult to imagine any agency willing to entertain Stallings and Karugendo's call for further research. Indeed, the topic is self-evidently a non-starter. Regardless of any evidence that might suggest an association, it is impossible to imagine a parallel research agenda [to the one on male circumcision] solidifying around the procedure, irrespective of whether the surgery was conducted in a medical context and [irrespective of] the extent of cutting involved.

The thought experiment can be taken a step further. With respect to causal plausibility, it is often argued that the biological mechanism through which the foreskin in males becomes a vector for HIV transmission (although the details are somewhat contentious) $)^{101,102}$ is the presence of Langerhans cells in the inner mucosa of the foreskin. What is rarely mentioned in these discussions, however, is that the external female genitalia are also richly endowed with Langerhans cells. ${ }^{103}$ If the removal of tissue with Langerhans cells is seen as an acceptable means of reducing HIV transmission, then the excision of portions of the female genitalia (on these grounds) should logically be entertained as well.

The point here is not to suggest that there is in fact good evidence that certain forms of FGA could definitely reduce 
the risk of male-to-female transmission of HIV; as it stands, that is not the case. Instead, the point is that regardless of any evidence for such a possibility, serious research into the question is unlikely ever to be considered, simply because such procedures are unacceptable to Western ethical and cultural norms. ${ }^{104}$ Bell has highlighted the contradictory policies of international health organizations on this point, "which seek to medicalize male circumcision on the one hand, oppose the medicalization of female circumcision on the other, while simultaneously basing their opposition to female operations on grounds that could legitimately be used to condemn the male operations." ${ }^{26}$

\section{Is there a "symbolic" difference?}

The analysis in the preceding section suggests that a benefit vs harm analysis cannot rule out, in a principled fashion, all forms of FGA, while simultaneously tolerating, much less promoting, the most common forms of MGA. This is because the health benefits that have been attributed to male circumcision, at least in a Western context, are relatively minor (in terms of absolute risk reduction); they apply mostly after an age of sexual debut; they can be achieved in much less harmful ways (such as by the adoption of safe sex practices); and - crucially for the sake of the present analysis - we do not actually know that certain minor forms of FGA would not confer the same degree of prophylaxis against disease. ${ }^{20}$ In the latter case, however, it seems unlikely that any such surgery would be seen as proportionate to the desired outcome (given alternatives): indeed, it is illegal to pursue the question. With respect to harms, on the other hand, I have tried to show that the adverse effects of both MGA and FGA overlap substantially, and that it is only by focusing on the least harmful forms of the former, and the most harmful forms of the latter, that this fact is not more widely understood.

But there may be a "symbolic" difference to consider as well. This is the view suggested by the philosopher Joseph Mazor, as indicated in the introduction, and it is one that has been advanced by Martha Nussbaum, among many others. "Female genital mutilation is unambiguously linked to customs of male domination," 105 Nussbaum has written; whereas male circumcision is not ordinarily seen as being linked to such customs, nor perhaps to other problematic norms. ${ }^{106}$

In contrast to this perspective, I suggest that male genital cutting can indeed "be understood as a gendering practice tied to [patriarchal notions of] masculinity" as well as to customs of male domination; ${ }^{107}$ and also, following Ahmadu, ${ }^{108}$ that female forms of genital cutting are not "unambiguously" tied to such customs, as Nussbaum and others seem to assume.

\section{The symbolic meanings of FGA}

Let me begin with the latter case. As is increasingly being emphasized by scholars in this area, female genital cutting is performed for different reasons in different social contexts, and is not always associated with a lower status for women and girls, nor with the aim of reducing their sexual pleasure. ${ }^{49,108}$ Indeed, such cutting is nearly always carried out by women themselves, who do not typically view their rites as being an expression of patriarchal norms, but rather as conducive to good hygiene, beautifying, ${ }^{37,109}$ empowering, and as a rite of passage with high cultural value. ${ }^{37,108}$ As Lisa Wade has argued, "attributing [the] persistence [of female genital altering rites] to patriarchy grossly oversimplifies their social, cultural, and economic functions" in the diverse societies in which they are performed. ${ }^{110}$

It has sometimes been argued that women who endorse FGA are victims of "false consciousness" and are thus mistaken about the nature of their own most cherished customs that they are so oppressed, for example, that they have become unwitting instruments to their own oppression. ${ }^{111}$ However, this sort of argument is increasingly being seen as both simplistic and condescending. ${ }^{11,37,111-114}$ As Dustin Wax has argued, the supportive voices of women who have actually undergone genital alterations "is almost entirely absent, literally silenced by [a Western] insistence that the horrendousness of the practice precludes any possible positive evaluation."115

Of course, popular opinion has only limited value as a guide to the moral status of a given practice. It is quite possible that those women who approve of FGA in their societies possess a comparatively narrow degree of awareness of the key issues, such as the relevant genital anatomy, the ethical controversies surrounding the practice, the way it is perceived in other societies, and so on. (If so, then they would not be altogether different, in this respect, from circumcised men in the United States - including many members of the medical profession - who typically know little to nothing about the anatomy and functions of the foreskin, and who may be unaware that circumcision is rare in other developed nations outside of religious communities). ${ }^{22,85,116-118}$ In support of this view, there is some evidence - from Nigeria, for example - that an increase in parental education corresponds to a reduction in the likelihood that the daughter will be "circumcised," although in other contexts, an increase in parental education corresponds, not to the abandonment of FGA, but rather to its medicalization ${ }^{104}$ (somewhat akin to MGA in the United States). ${ }^{59,119}$

As Francelle Wax, a Jewish filmmaker and critic of both FGA and MGA has argued (personal communication, January 18, 2015): 
It would be productive to encourage people away from relying on majority opinion to determine what is ethically acceptable (or what people would [endorse] had they not been primed by their culture's norms). As most people are not [inclined to be] norm-questioning ... and are hard-wired to rationalize irreparable harm done to them, or harm they caused to another, it is both unsurprising and un-compelling to note that the majority of people from cutting cultures do not object to having been cut [or see the practice as being unproblematic]. People should be encouraged to look to dissenting minorities, not to the masses, to take their cues about what is ethically problematic.

Notwithstanding Wax's important insight, as Ahmadu has argued, there has been an "unjustified conflation" of the varied practices of FGA in the popular discourse, resulting in an overemphasis on the most symbolically problematic form, namely infibulation or pharaonic circumcision. ${ }^{108}$ This conflation is unjustified, she suggests, because infibulation is simultaneously the most extreme form of FGA, the rarest, and the form most closely associated with norms of male dominance and sexual control. It is also "associated with a specific region and interpretation of Muslim purdah ideology,"108 and appears to be concentrated in north-east Africa.

In most other African contexts, by contrast, both FGA and MGA are least superficially egalitarian: they are carried out regardless of the sex or gender of the child, and are intended as a means of conferring adult status within the group. ${ }^{49,104}$ Among the Kono of Sierra Leone, for example, "there is no cultural obsession with feminine chastity, virginity, or women's sexual fidelity, perhaps because the role of the biological father is considered marginal and peripheral to the central 'matricentric unit." 108 In this context, male and female genital alterations are performed in parallel ceremonies, are not primarily intended to reduce sexual pleasure, and the operations are seen as mirror images of each other. ${ }^{11,49,104}$

Nancy Ehrenreich and Mark Barr provide a general lesson:

$[\ldots]$ the mainstream anti-FG[A] position is premised upon an orientalizing construction of FG[A] societies as primitive, patriarchal, and barbaric, and of female circumcision as a harmful, unnecessary cultural practice based on patriarchal gender norms and ritualistic beliefs. ... Lambasting African societies and practices (while failing to critique similar practices in the United States [and Europe]) ... essentially implies that North American [and European] understandings of the body are "scientific" (ie, rational, civilized, and based on universally acknowledged expertise), while African understandings are "cultural" (ie, superstitious, un-civilized, and based on false, socially constructed beliefs). [Yet] neither of these depictions is accurate. North American medicine is not free of cultural influence, and FG[A] practices are not bound by culture - at least not in the uniform way imagined by opponents. ${ }^{4}$

\section{The symbolic meanings of MGA}

What about the other side of things? The usual claim is that male circumcision is not associated with a lowered status for women, but in Judaism, at least, this is not obviously the case. Indeed, only the males are permitted to "seal the divine covenant" by having their foreskins removed, so the custom is sexist on its face. ${ }^{21}$ In his analysis of why Jewish women are not circumcised, Shaye J D Cohen argues that "Jews of antiquity seem not to have been bothered by this question probably because the fundamental Otherness of women was clear to them. Jewish women were Jewish by birth, but their Jewishness was assumed to be inferior to that of Jewish men." ${ }^{20,121}$ Thus, as David Benatar has pointed out, "half of the Jewish people lack the physical mark that is widely associated with Jews. One would have thought that egalitarians would want to rectify this oversight.". ${ }^{22}$ As he goes on to state, "A true egalitarian would think it unfair that a boy is cut while a girl is not [and would] either extend the burden [of circumcision] to girls or remove it from [the] boys." ${ }^{22}$ The sociologist Michael Kimmel goes a step further:

circumcision means ... the reproduction of patriarchy. [In the Jewish tradition] Abraham cements his relationship to God by a symbolic genital mutilation of his son. It is on the body of his son that Abraham writes his own beliefs. In a religion marked by the ritual exclusion of women, such a marking not only enables Isaac to be included within the community of men ... but he can also lay claim to all the privileges to which being a Jewish male now entitles him..... To circumcise [one's son, therefore, is] to accept as legitimate 4000 years [of] patriarchal domination of women. ${ }^{123}$

Male circumcision may be related to other problematic norms as well. One connection that has been raised in the literature is with an attempt to exercise control over boys' sexualities. ${ }^{21,124}$ While most contemporary Western parents who choose circumcision for their sons do not (very likely) have such a motivation consciously in mind, neither, apparently, do most African parents when they choose "circumcision" for their daughters. Instead, as the renowned anti-FGA activist Hanny Lightfoot-Klein has stated: "The [main] 
reasons given for female circumcision in Africa and for routine male circumcision in the United States are essentially the same. Both promise cleanliness and the absence of odors as well as greater attractiveness and acceptability." 25

Nevertheless, male genital cutting has indeed been used as a form of sexual control, and even punishment, for a very long time. ${ }^{21,124}$ The Jewish philosopher Maimonides (b. 1135) argued that diminished sexual sensitivity was part of the point of performing circumcisions (to reduce excessive "lust" as well as "weaken ... the organ in question"); ${ }^{126}$ circumcision was adopted into Western medicine in the Victorian period largely as a means to combat masturbation and other expressions of juvenile sexuality; ${ }^{127}$ and forced circumcision of (male) enemies has been used as a means of humiliation since time immemorial: the Luo of Kenya, for example, who do not traditionally circumcise, have been victims of such attacks in recent times, as have numerous other groups, including Christians in Aceh, Indonesia. ${ }^{128-130}$

Here, too, it could be argued that these apparent associations with problematic norms are superficial, ${ }^{131}$ outdated, or only apply to a limited number of cases. But this is exactly the point. Neither male nor female forms of genital cutting can be successfully "boiled down" in terms of the attitudes that they supposedly express, and both have been plausibly associated with both (seemingly) unproblematic as well as (seemingly) extremely problematic norms. Yet if these interventions are meant to be distinguishable in terms of their permissibility on account of the differing norms that they are taken to reflect, then they will be very hard to distinguish indeed. As I have noted elsewhere:

Given that both male and female forms of genital cutting express different cultural norms depending upon the context, and are performed for different reasons in different cultures, and even in different communities or individual families, how shall we assess the permissibility of either? Do we need to interview each set of parents to make sure that their proposed act of cutting is intended as an expression of acceptable norms? If they promise that it isn't about 'sexual control' in their specific case, but rather about 'hygiene' or 'aesthetics' or something less symbolically problematic, should they be permitted to go ahead? But this is bound to fail. ${ }^{82}$

\section{Toward an autonomy-based ethical framework}

Let me take stock of where we are. So far, I have been questioning the dominant moral paradigm according to which non-therapeutic genital alterations performed on children are treated fundamentally differently, depending upon the sex or gender of the child whose genitals are altered. I have tried to show that such differential treatment cannot be maintained on unambiguous and principled grounds, neither on the basis of a harm-based analysis, nor on the basis of differing "symbolic meanings." At the very least, I claim that the ordinary distinctions that are maintained, including by powerful decision-making bodies with considerable influence on a global scale, ${ }^{11}$ are morally inconsistent.

At a first glance, there seem to be at least two ways of resolving this inconsistency. First, if Western societies remain convinced that the non-therapeutic alteration of boys' genitalia should be considered permissible so long as it does not cross an arbitrary threshold of "harm," then they should consider allowing similar alterations to the genitals of little girls (if requested by the parents). Some authors most notably Dena Davis ${ }^{21}$ - have in fact made just such a suggestion. ${ }^{11,132,133}$ It seems evident, however, that this "solution" would create more problems than it would solve. For example, it would require that Western laws regarding physical assault on a minor be rewritten, potentially creating large-scale disturbances throughout the legal system. This is because - as others have argued - cutting into a child's genitals without a medical diagnosis, and without its informed consent, meets the formal definition of criminal assault under the legal codes of most of these societies. ${ }^{134}$ For example, as Svoboda, Adler, and Van Howe point out in a forthcoming paper with respect to the legal situation in the United States, "In banning non-therapeutic FGC ['female genital cutting'] in 1997, Congress stated that it 'infringes upon the guarantees of rights secured by Federal and State law, both statutory and constitutional.' That is to say, female genital cutting was already unlawful" prior to the enactment of specific legislation. ${ }^{135}$

Another problem, acknowledged by Davis, is that it would be very difficult indeed to "police" such newly approved "minimal" forms of FGA, to ensure that they were not being used as a cover for more invasive and harmful procedures. In fact, a very basic problem with the suggestion of harmtolerance is the difficulty it presents in terms of specifying an appropriate threshold for harm that could be measured in an objective way. As Blackstone noted more than 200 years ago, "the law cannot draw [a] line between different degrees of violence." ${ }^{\prime 136}$ Accordingly, as Robert Ludbrook explains, "Once the laws permit physical violence, decisions have to be made as to where within the continuum of violence the limits are to be fixed." 136 This could open the door for interested parties to argue, for any proposed act of cutting, that it is 'not harmful enough' to warrant the placement of 
limitations on parental decision making. As Ludbrook argues, "The law is an important symbol and if [it] allows parents, carers and teachers to [so much as hit their] children, it is sending a message to these people and to the community generally that children are not entitled to the same right to bodily integrity as adults." 136

The question of rights is arguably central to this issue. In Western societies, we teach our citizens (including our children) that they have a right to bodily integrity: ${ }^{117}$ "a right to make decisions about what happens to [their] own body, [a] right to say no to unwanted touching, [a] right not to be physically or sexually assaulted." 136 This, Ludbrook argues, is "the most personal and arguably the most important of all human rights," next to the right to life itself. ${ }^{136}$ Some authors have argued that FGA performed before an age of consent is a violation of such a right, "regardless of the degree of cutting or the extent of the complications that may or may not ensue."'

Undoubtedly, such a view is motivated at least in part by the fact that such cutting involves a very "private" part of the body - ie, a part with unique psycho-sexual significance - and that it is done before a girl can understand what is at stake in such a procedure, much less offer effective resistance. Indeed, genitals are not like other parts of the body. This can be seen in the fact that sexual assault, in Western societies, is typically regarded as a more severe and more personal violation than other kinds of bodily assault. Accordingly, the outright cutting and/or alteration of a child's genitals seems much more likely to be the sort of interference that would later be experienced as a harm, compared against various other childhood bodily alterations that are sometimes raised in the literature.

\section{A child's right to bodily integrity: genital cutting vs. other alterations}

Consider vaccinations, which some authors have suggested are morally, or even physically, equivalent to male circumcision. ${ }^{137}$ Against this view, critics point out that vaccination does not remove erogenous tissue (nor any healthy tissue), nor does it risk harming sexual function, sensation, or satisfaction. In addition, it does not result in a visible change to the appearance of the body, much less a part of the body with respect to which aesthetic norms, feelings of self-esteem, etc, vary considerably from person to person, and often inspire very strong feelings. ${ }^{62,137,138}$

Orthodontic treatment is another childhood bodily modification that is sometimes compared with genital cutting. ${ }^{139}$ Similar to vaccinations, dental braces do not remove nor risk damaging erogenous tissue, ${ }^{\mathrm{k}}$ and (moreover) they are usually put on with the age-appropriate consent of the affected individual. Although braces may be uncomfortable, and although they do make a difference to physical appearance, both the degree of discomfort and the type of alteration to appearance fall well within the child's understanding. In contrast, the permanent modification of genital tissue prior to an age of sexual debut is not something whose significance a child of any sex or gender is in a position to fully understand. ${ }^{11}$

Finally, consider minor cleft lip repair - another common "analogy" to male circumcision. ${ }^{31}$ While this is typically done before a child understands what is at stake in the procedure, it likewise does not remove functional tissue that he or she might later value (and wish to have experienced intact); indeed, it is universally regarded as a means of repairing a defect and thus as a form of cosmetic enhancement. This is in contrast to both FGA and MGA, whose respective statuses as being enhancements (as opposed to diminishments, ${ }^{140}$ or even mutilations ${ }^{106,138}$ ) are contentious even within the societies in which they have traditionally been performed. ${ }^{11,37,58}$

These (and other) differences between genital cutting and other types of body modification may help to explain why there is an active "genital autonomy"141 movement in the United States, Europe, and elsewhere that is fueled by women, men, and intersex people who are extremely resentful about their childhood genital surgeries, but not an anti-orthodontics movement or an anti-cleft lip-repair movement. ${ }^{23}$ (There is, of course, a very controversial anti-vaccination movement, but this is motivated, not by concerns about violations of a child's right to bodily integrity, but rather by unfounded concerns about vaccines contributing to an increased risk of autism and other problems). ${ }^{142}$

\section{A new ethical framework}

Taking all of these considerations into account, let me offer a second approach to resolving the "inconsistency" alluded to above, which has the potential to avoid the serious disadvantages that seem likely to follow from an increased tolerance for FGA. This approach would involve a decreased tolerance for MGA, and on the same grounds that have just been discussed. According to this approach, the test for moral permissibility (if not legal permissibility, as that may raise a different set of issues) ${ }^{143}$ would rest not so much on considerations of sex or gender - according to which boys, compared to girls,

${ }^{\mathrm{k}}$ They do pose a very small risk of damaging the lips, which might plausibly be considered erogenous tissue, but, in contrast to circumcision (in which the removal of dozens of square centimeters of erogenous tissue is a necessary component of the intervention itself), this would be an accidental side-effect, and one that is probably so rare as to be able to be discounted. 
are treated less favorably - but more on considerations of informed consent, reflecting an underlying concern for the "genital autonomy"141,144 of children.

Moira Dustin has described just such an approach. She suggests that one way to resolve the apparent double standard regarding male vs female forms of genital alteration in Western societies, "would be to argue for the application of consistent principles of choice ... and the recognition of all non-therapeutic bodily modifications" as being "culturally" motivated. ${ }^{114 \text { "This }}$ could mean making a distinction," she continues, "between adults who can choose how to modify their bodies in irreversible ways - however much the majority might deplore their choices - and children who cannot." ${ }^{114}$ The application of this framework would have several important implications:

It would mean saying that male circumcision of baby boys, where it has been established that it has no [net] ${ }^{*}$ medical benefits, is unacceptable; it would mean that it would be illegal to circumcise a girl under the age of consent; and it would mean [by contrast] that if an adult woman wants to have her genitals 'tidied up' after childbirth or her labia reduced through 'cosmetic' surgery, then she should be allowed to make that choice. This may not be a satisfactory position but it is a way of avoiding double standards while the real work of changing the attitudes that produce these practices takes place. ${ }^{114}$

I am sympathetic with this general framework. As I have argued elsewhere, "Children of whatever [sex or] gender should not have healthy parts of their most intimate sexual organs removed, before such a time as they can understand what is at stake in such a surgery and agree to it themselves."43 Conversely, as Christine Mason and others have argued, adults should be free to use medical technologies to modify their own bodies and minds, in a process of self-creation, if that is what they truly want. ${ }^{147-149}$ While I do not suggest that (nontherapeutic) MGA should be banned, necessarily, ${ }^{85,150,151}$ it is clear that the current laissez faire attitude toward this practice that is typical of Western societies - and in particular the

"I have added the word "net" here because this is a crucial distinction. Obviously removing any part of the body might reduce the risk of some disease afflicting that part of the body: tissue that has been excised cannot host an infection (for example). The relevant notion is net health benefits, then, because any benefits that might in fact accrue from the amputation of healthy tissue have to be balanced against not only the risk of surgical complications, but also the value of the lost tissue itself; the short-term, intermediate, and long-term adverse consequences associated with the intervention; ${ }^{145,146}$ and, in the case of genital operations in particular, the loss of choice concerning a very 'private' part of one's body. ${ }^{23,146}$ Moreover, there should be a paucity of less invasive, less risky alternatives for achieving the health benefits in question, for "health benefits"-type arguments to be compelling. ${ }^{20}$
United States - can no longer be maintained without facing serious objection. FGA and MGA are both highly problematic practices, with far more overlap between them (both physically and symbolically) than is commonly understood: they should not be discussed, therefore, in hermetically-sealed moral discourses. ${ }^{21,104}$ Instead, the relevant framework is one that analyses a child's right to bodily integrity, and carefully considers how tolerant we are willing to be, in these societies, of practices which irreversibly alter a person's "private parts" in a non-trivial fashion, in the absence of medical necessity, ${ }^{145}$ and before the person has a chance to say "no."

\section{About the author}

Brian D Earp is a scientist and ethicist. He holds degrees from Yale, Oxford, and Cambridge Universities, including an M.Phil. degree in the history, philosophy, and sociology of science and medicine, focusing on male and female genital altering surgeries. Brian has served as a Guest Editor for the Journal of Medical Ethics, editing a special issue on the topic of childhood circumcision, and has published widely in the leading journals in his field.

\section{Acknowledgements}

Portions of this essay have been adapted from an informal blog post by the author entitled, "Female Genital Mutilation (FGM) and male circumcision: Should there be a separate ethical discourse?" available at: http://blog.practicalethics. ox.ac.uk/2014/02/female-genital-mutilation-and-malecircumcision-time-to-confront-the-double-standard $/ .{ }^{43}$ Please note that a revised and shortened version of this post was subsequently published as "Boys and girls alike" by Aeon Magazine, available at http://aeon.co/magazine/philosophy/ male-and-female-circumcision-are-equally-wrong/. ${ }^{82} \mathrm{~A}$ handful of sentences in the present article have been adapted from this revised version. Finally, thanks are due to Erik Parens and his colleagues at The Hastings Center for discussing with me some of the core ideas that form the basis of this paper, as well as to Michael Thompson, Joseph Mazor, Rebecca Steinfeld, Robert Darby, Ashley Trueman, and Alex Myers for providing feedback on earlier drafts.

\section{Disclosure}

The author reports no conflicts of interest in this work.

\section{References}

1. Rahman A, Toubia N. Female Genital Mutilation: A Practical Guide to Worldwide Laws and Policies: Zed Books; 2000.

2. Morris B. Science supports infant circumcision, so should skeptics. The Skeptic. 2013;Autumn:30-33. 
3. Unger RK, Crawford M. Commentary: Sex and gender: the troubled relationship between terms and concepts. Psychological Science. 1993;4(2):122-124.

4. Ehrenreich N, Barr M. Intersex surgery, female genital cutting, and the selective condemnation of cultural practices. Harvard Civil Rights-Civil Liberties Law Review. 2005;40:71-539.

5. Dreger AD. "Ambiguous sex" - or ambivalent medicine? Ethical issues in the treatment of intersexuality. Hastings Center Report. 1998;28(3): 24-35.

6. Hester JD. Intersex(es) and informed consent: how physicians' rhetoric constrains choice. Theoretical Medicine and Bioethics. 2004;25(1): 21-49.

7. Parens E. Surgically Shaping Children: Technology, Ethics, and the Pursuit of Normality: JHU Press; 2006.

8. Carmack A, Notini L, Earp BD. Should surgery for hypospadias be performed before an age of consent? Journal of Sex Research. In press. Available online ahead of print at https://www.academia.edu/13117940/ Should_surgery_for_hypospadias_be_performed_before_an_age_of_ consent.

9. United Nations Population Fund. Promoting Gender Equality. 2014. Available at http://www.unfpa.org/gender/practices2.htm\#12.

10. UN Women. United Nations Bans Female Genital Mutilation. 2012 Available at http://www.unwomen.org/en/news/stories/2012/12/unitednations-bans-female-genital-mutilation/.

11. Earp, BD. Between moral relativism and moral hypocrisy: reframing the debate on "FGM." Kennedy Institute of Ethics Journal. In press. Available online ahead of print at https://www.academia.edu/10197867/ Between_moral_relativism_and_moral_hypocrisy_The_case_of_ FGM.

12. Van den Brink M, Tigchelaar J. Shaping genitals, shaping perceptions: a frame analysis of male and female circumcision. Netherlands Quarterly of Human Rights. 2012;30:417-445.

13. Geisheker JV. The completely unregulated practice of male circumcision: human rights' abuse enshrined in law? New Male Studies. 2013;2(1):18-45.

14. Solomon LM, Noll RC. Male versus female genital alteration: differences in legal, medical, and socioethical responses. Gender Medicine. 2007;4(2):89-96.

15. Giami A, Perrey C, de Oliveira Mendonça AL, de Camargo KR. Hybrid forum or network? The social and political construction of an international 'technical consultation': male circumcision and HIV prevention. Global Public Health. 2015;10(5-6):589-606.

16. AAP. Male circumcision. Pediatrics. 2012;130(3):e746-e785.

17. CDC. Recommendations for Providers Counseling Male Patients and Parents Regarding Male Circumcision and the Prevention of HIV Infection, STIs, and Other Health Outcomes. 2014. Available at http://www. regulations.gov/\#!documentDetail; $\mathrm{D}=\mathrm{CDC}-2014-0012-0003$.

18. CDC. Draft CDC Recommendations for Providers Counseling Male Patients and Parents Regarding Male Circumcision and the Prevention of HIV Infection, STIs, and Other Health Outcomes. 2014. Available at http://www.cdc.gov/nchhstp/newsroom/docs/ MC-factsheet-508.pdf.

19. World Health Organization. Male Circumcision for HIV Prevention. 2015. Available at http://www.who.int/hiv/topics/malecircumcision/ en/.

20. Earp BD. Do the benefits of male circumcision outweigh the risks? A critique of the proposed CDC guidelines. Frontiers in Pediatrics. 2014;3(18):1-6.

21. Davis DS. Male and female genital alteration: a collision course with the law. Health Matrix. 2001;11:487-687.

22. Cold CJ, Taylor JR. The prepuce. BJU International. 1999;83(S1): 34-44.

23. Earp BD. Sex and circumcision. American Journal of Bioethics. 2015;15(2):43-45.

24. Dekkers W, Hoffer C, Wils J-P. Bodily integrity and male and female circumcision. Medicine, Health Care and Philosophy. 2005;8(2): 179-191.
25. Svoboda JS, Darby R. A rose by any other name: symmetry and asymmetry in male and female genital cutting. In Fearful Symmetries: Essays and Testimonies Around Excision and Circumcision, ed. Zabus C. Amsterdam and New York: Rodopi. 2008;272-286.

26. Bell K. Genital cutting and Western discourses on sexuality. Medical Anthropology Quarterly. 2005;19(2):125-148.

27. Schwartz RL, Johnson D, Burke N. Multiculturalism, medicine, and the limits of autonomy: the practice of female circumcision. Cambridge Quarterly of Healthcare Ethics. 1994;3(3):431-441.

28. World Health Organization. Female Genital Mutilation. 2014. Available at http://www.who.int/mediacentre/factsheets/fs241/en/.

29. Tobian AA, Gray RH. The medical benefits of male circumcision. Journal of the American Medical Association. 2011;306(13): 1479-1480.

30. Blank S, Brady M, Buerk E, et al. Circumcision policy statement. Pediatrics. 2012;130(3):585-586.

31. Mazor J. The child's interests and the case for the permissibility of male infant circumcision. Journal of Medical Ethics. 2013;39(7): 421-428.

32. World Health Organization. Global Strategy to Stop Healthcare Providers from Performing Female Genital Mutilation. 2010. Available at http://whqlibdoc.who.int/hq/2010/WHO_RHR_10.9_eng.pdf?ua=1.

33. Renganathan A, Cartwright R, Cardozo L. Gynecological cosmetic surgery. Expert Review of Obstetrics and Gynecology. 2009;4(2):101-104.

34. Cold CJ, McGrath KA. Anatomy and histology of the penile and clitoral prepuce in primates. Male and Female Circumcision. New York: Springer. 1999;19-29.

35. O'Connell HE, Sanjeevan KV, Hutson JM. Anatomy of the clitoris. The Journal of Urology. 2005;174(4):1189-1195.

36. Liao L-M, Taghinejadi N, Creighton SM. An analysis of the content and clinical implications of online advertisements for female genital cosmetic surgery. BMJ Open. 2012;2(6):e001908.

37. Shell-Duncan B, Hernlund Y. Female "Circumcision" in Africa: Culture, Controversy, and Change: Boulder: Lynn Reinner Publishers; 2000.

38. Rodriguez, S. Female Circumcision and Clitoridectomy in the United States: A History of a Medical Treatment. University of Rochester Press; 2014.

39. Kelly B, Foster C. Should female genital cosmetic surgery and genital piercing be regarded ethically and legally as female genital mutilation? BJOG: An International Journal of Obstetrics and Gynaecology. 2012;119(4):389-392.

40. Sheldon S, Wilkinson S. Female genital mutilation and cosmetic surgery: regulating non-therapeutic body modification. Bioethics. 1998;12(4):263-285.

41. MacReady N. AAP retracts statement on controversial procedure. The Lancet. 2010;376(9734):15.

42. Brady M. Female genital mutilation: complications and risk of HIV transmission. AIDS Patient Care and STDs. 1999;13(12):709-716.

43. Earp BD. Female genital mutilation (FGM) and male circumcision: Should there be a separate ethical discourse? Practical Ethics. University of Oxford. 2014. Available at https://www.academia.edu/8817976/ Female_genital_mutilation_FGM_and_male_circumcision_Should_ there_be_a_separate_ethical_discourse.

44. Obermeyer CM. Female genital surgeries: the known, the unknown, and the unknowable. Medical Anthropology Quarterly. 1999;13(1): 79-106.

45. Chambers C. Are breast implants better than female genital mutilation? Autonomy, gender equality and Nussbaum's political liberalism. Critical Review of International Social and Political Philosophy. 2004;7(3):1-33.

46. Shell-Duncan B. The medicalization of female "circumcision": harm reduction or promotion of a dangerous practice? Social Science and Medicine. 2001;52(7):1013-1028.

47. Shell-Duncan B, Hernlund Y. Female circumcision in Africa: dimensions of the practice and debates. In Female "Circumcision" in Africa: Culture, Controversy, and Change, ed. Shell-Duncan B, Hernlund Y. Boulder: Lynne Rienner Publishers; 2000:1-40. 
48. Toubia N. Female Genital Mutilation: A Call for Global Action. New York: Rainbow/Women Ink. 1993.

49. Abdulcadir J, Ahmadu FS, Catania L, et al. Seven things to know about female genital surgeries in Africa. Hastings Center Report. 2012;42(6): 19-27.

50. Catania L, Abdulcadir O, Puppo V, Verde JB, Abdulcadir J, Abdulcadir D. Pleasure and orgasm in women with female genital mutilation/cutting (FGM/C). The Journal of Sexual Medicine. 2007;4(6):1666-1678.

51. Johnsdotter S. Discourses on sexual pleasure after genital modifications: the fallacy of genital determinism (a response to J Steven Svoboda). Global Discourse. 2013;3(2):256-265.

52. Alsibiani SA, Rouzi AA. Sexual function in women with female genital mutilation. Fertility and Sterility. 2010;93(3):722-724.

53. Berg RC, Denison E, Fretheim A. Psychological, social and sexual consequences of female genital mutilation/cutting (FGM/C): a systematic review of quantitative studies. Report from Kunnskapssenteret. 2010;13:3-77.

54. Berg RC, Denison E. Does female genital mutilation/cutting (FGM/C) affect women's sexual functioning? A systematic review of the sexual consequences of FGM/C. Sexuality Research and Social Policy. 2012;9(1):41-56.

55. Obermeyer $\mathrm{C}$. The consequences of female circumcision for health and sexuality: an update on the evidence. Culture, Health and Sexuality. 2005;7(5):443-461.

56. Meston CM, Hull E, Levin RJ, Sipski M. Disorders of orgasm in women. The Journal of Sexual Medicine, 2004;1(1):66-68.

57. Fahmy A, El-Mouelhy MT, Ragab AR. Female genital mutilation/ cutting and issues of sexuality in Egypt. Reproductive Health Matters. 2010;18(36):181-190.

58. Glick LB. Marked in Your Flesh: Circumcision from Ancient Judea to Modern America. Oxford: Oxford University Press; 2005.

59. Gollaher DL. From ritual to science: the medical transformation of circumcision in America. Journal of Social History. 1994;28(1):5-36.

60. Taylor JR, Lockwood AP, Taylor A. The prepuce: specialized mucosa of the penis and its loss to circumcision. BJU International. 1996;77(2):291-295.

61. Werker PM, Terng AS, Kon M. The prepuce free flap: dissection feasibility study and clinical application of a super-thin new flap. Plastic and Reconstructive Surgery. 1998;102(4):1075-1082.

62. Earp BD, Darby R. Does science support infant circumcision? The Skeptic. 2015;25(3):23-30.

63. Scott S. The anatomy and physiology of the human prepuce. Male and Female Circumcision. New York: Springer. 1999;9-18.

64. Frisch M, Lindholm M, Grønbæk M. Male circumcision and sexual function in men and women: a survey-based, cross-sectional study in Denmark. International Journal of Epidemiology. 2011;40(5):1367-1381.

65. Morris BJ, Waskett JH, Gray RH. Does sexual function survey in Denmark offer any support for male circumcision having an adverse effect? International Journal of Epidemiology. 2012;41(1):310-326.

66. Frisch, M. Author's Response to: Does sexual function survey in Denmark offer any support for male circumcision having an adverse effect? International Journal of Epidemiology. 2012;41(1):312-314.

67. Morris BJ, Krieger JN. Does male circumcision affect sexual function, sensitivity, or satisfaction? - A systematic review. The Journal of Sexual Medicine. 2013;10(11):2644-2657.

68. Bossio JA, Pukall CF, Steele S. A review of the current state of the male circumcision literature. The Journal of Sexual Medicine. 2014;11(12): $2847-2864$.

69. Earp BD. Addressing polarization in science. Journal of Medical Ethics. 2015;41:782-784.

70. Earp BD. How can journal editors fight bias in polarized scientific communities? Journal of Medical Ethics Blog. 2015. Available at http:// blogs.bmj.com/medical-ethics/2015/04/30/how-can-journal-editorsfight-bias-in-polarized-scientific-communities/.

71. Aberson C. Interpreting null results: Improving presentation and conclusions with confidence intervals. Journal of Articles in Support of the Null Hypothesis. 2002;1(3):36-42.
72. Rizvi SA, Naqvi S, Hussain M, Hasan A. Religious circumcision: a Muslim view. BJU International. 1999;83(S1):13-16.

73. Stang HJ, Snellman LW. Circumcision practice patterns in the United States. Pediatrics. 1998;101(6): e5.

74. Davis DS. Ancient rites and new laws: how should we regulate religious circumcision of minors? Journal of Medical Ethics. 2013;39(7):456-458.

75. Pounder DJ. Ritual mutilation: subincision of the penis among Australian Aborigines. The American Journal of Forensic Medicine and Pathology. 1983;4(3):227-230.

76. Willis J. Heteronormativity and the deflection of male same-sex attraction among the Pitjantjatjara people of Australia's Western Desert. Culture, Health and Sexuality. 2003;5(2):137-151.

77. Anike U, Govender I, Ndimande JV, Tumbo J. Complications of traditional circumcision amongst young Xhosa males seen at St Lucy's Hospital, Tsolo, Eastern Cape, South Africa: original research. African Primary Health Care and Family Medicine. 2013;5(1):1-5.

78. Gonzalez L. South Africa: over half a million initiates maimed under the knife. All Africa. 2014. Available at http://allafrica.com/ stories/201406251112.html.

79. Maseko N. When circumcision can mean death in South Africa. $B B C$ News Africa. 2013. Available at http://www.bbc.co.uk/news/worldafrica-23378694.

80. Checketts R. Response to freedom of information request, FOI/0742. Birmingham Children's Hospital, NHS Foundation Trust. 2012. Available at http://www.secularism.org.uk/uploads/foi-bch-responsereceived-260612.pdf.

81. DeLaet DL. Framing male circumcision as a human rights issue? Contributions to the debate over the universality of human rights. Journal of Human Rights. 2009;8(4):405-426.

82. Earp BD. Boys and girls alike. Aeon Magazine. 2015. Available at http://aeon.co/magazine/philosophy/male-and-female-circumcisionare-equally-wrong/.

83. Androus ZT. The United States, FGM, and Global Rights to Bodily Integrity. Paper presented at The Rothermere American Institute Conference: The United States and Global Human Rights. November, 2004. Oxford University. Available at http://www.zacharyandrous.com/ The\%20US\%20FGM\%20and\%20Global\%20HR.pdf.

84. Garenne M, Giami A, Perrey C. Male circumcision and HIV control in Africa: questioning scientific evidence and decision making process. In Global Health in Africa: Historical Perspectives on Disease Control, ed. Giles-Vernick T, Webb JLA Jr. Athens, Ohio: Ohio University Press. 2013:185-210.

85. Earp BD. The ethics of infant male circumcision. Journal of Medical Ethics. 2013;39(7):418-420.

86. Frisch M, Aigrain Y, Barauskas V, et al. Cultural bias in the AAP's 2012 Technical Report and Policy Statement on male circumcision. Pediatrics. 2013;131(4):796-800.

87. Svoboda JS, Van Howe RS. Out of step: fatal flaws in the latest AAP policy report on neonatal circumcision. Journal of Medical Ethics. 2013;39(7):434-441.

88. Garber ST. The Circular Cut: Problematizing the Longevity of Civilization's Most Aggressively Defended Amputation. Wesleyan University; 2013.

89. Hartmann W. Expert statement: Dr med. Wolfram Hartmann, President of "Berufsverband der Kinder- und Jugendärzte" [German Pediatric Society] for the hearing on the 26th of November 2012 concerning the drafting of a federal government bill. Berufsverband der Kinderund Jugendärzte (BVKJ). 2012. German original available at http:// www.kinderaerzte-im-netz.de/bvkj/kinpopup/psfile/pdf/70/121126_ Ste50aa5e211e6a6.pdf; English translation available at: http://www. intactamerica.org/german_pediatrics_statement.

90. Lawson C. Re: AAP circumcision Policy Statement and Technical Report. Pediatrics. 2012;E-letter. Available at http://pediatrics.aappublications. org/content/130/3/e756.full/reply\#pediatrics_el_54322.

91. Booker CS. Re: Technical report on male circumcision. Pediatrics. 202;E-letter. Available at http://pediatrics.aappublications.org/ content/130/3/e756.full/reply\#pediatrics_el_54322. 
92. Bewley S, Stranjord S. Being honest about medical involvement that contravenes "first of all, do no harm." Pediatrics. 2012;E-letter. Available at http://pediatrics.aappublications.org/content/130/3/585. short/reply\#pediatrics_el_55563.

93. Guest C. Revised male infant circumcision policy: a disservice to Americans. Pediatrics. 2012;E-letter. Available at http://pediatrics.aappublications.org/content/130/3/585.short/ reply\#pediatrics_el_55563.

94. Androus ZT. Critiquing circumcision: in search of a new paradigm for conceptualizing genital modification. Global Discourse. 2013;3(2):266-280.

95. Earp BD. The AAP report on circumcision: bad science + bad ethics $=$ bad medicine. Practical Ethics. University of Oxford. 2012. Available at http://blog practicalethics ox ac uk/2012/08/the-aap-report-oncircumcision-bad-science-bad-ethics-bad-medicine/.

96. Wettergren B, Jodal U, Jonasson G. Epidemiology of bacteriuria during the first year of life. Acta Paediatrica Scandinavica. 1985;74:925-933.

97. Benatar M, Benatar D. Between prophylaxis and child abuse: the ethics of neonatal male circumcision. American Journal of Bioethics. 2003;3(2):35-48.

98. Singh-Grewal D, Macdessi J, Craig J. Circumcision for the prevention of urinary tract infection in boys: a systematic review of randomised trials and observational studies. Archives of Disease in Childhood. 2005;90(8):853-858.

99. Stallings RY, Karugendo E. Female circumcision and HIV infection in Tanzania: for better or for worse. Third International AIDS Society Conference on HIV Pathogenesis and Treatment Rio de Janeiro. 2005:25-27.

100. Kinuthia RG. The Association Between Female Genital Mutilation (FGM) and the Risk of HIV/AIDS in Kenyan Girls and Women (15-49 Years). Georgia State University. 2010. Available at http://scholarworks.gsu. edu/cgi/viewcontent.cgi? article $=1113 \&$ context $=$ iph_theses.

101. Van Howe RS. A CDC-Requested, Evidence-Based Critique of the Centers for Disease Control and Prevention 2014 Draft on Male Circumcision: How Ideology and Selective Science Lead to Superficial, Culturally-Biased Recommendations by the CDC. 2015. Available at https://www.academia.edu/10553782/A_CDCrequested_Evidence-based_Critique_of_the_Centers_for_Disease_ Control_and_Prevention_2014_Draft_on_Male_Circumcision_How_ Ideology_and_Selective_Science_Lead_to_Superficial_Culturallybiased_Recommendations_by_the_CDC.

102. de Witte L, Nabatov A, Pion M, et al. Langerin is a natural barrier to HIV-1 transmission by Langerhans cells. Nature Medicine. 2007;13(3):367-371.

103. Edwards JNT, Morris, HB. Langerhans' cells and lymphocyte subsets in the female genita1 tract. BJOG: An International Journal of Obstetrics \& Gynaecology. 1985;92(9):974-982.

104. Caldwell JC, Orubuloye IO, Caldwell P. Male and female circumcision in Africa from a regional to a specific Nigerian examination. Social Science and Medicine. 1997;44(8):1181-1193.

105. Nussbaum MC. Sex and Social Justice. Oxford: Oxford University Press; 1999

106. Johnson M. Male genital mutilation: beyond the tolerable? Ethnicities. 2010;10(2):181-207.

107. Fox M, Thomson M. Foreskin is a feminist issue. Australian Feminist Studies. 2009;24(60):195-210.

108. Ahmadu F. Rites and wrongs: an insider/outsider reflects on power and excision. In Female "Circumcision” in Africa: Culture, Controversy, and Change. 2000:283-312.

109. Manderson L. Local rites and body politics: tensions between cultural diversity and human rights. International Feminist Journal of Politics. 2004;6(2):285-307.

110. Wade L. Learning from "Female Genital Mutilation": lessons from 30 years of academic discourse. Ethnicities. 2012;12(1):26-49.

111. James SM, Robertson CC. Genital Cutting and Transnational Sisterhood: Disputing US Polemics. Chicago: University of Illinois Press; 2002 .
112. Kirby V. On the cutting edge: feminism and clitoridectomy. Australian Feminist Studies. 1987;2(5):35-55.

113. Shaheed F. Constructing identities: culture, women's agency and the Muslim world. International Social Science Journal. 1999;51(159):61-73.

114. Dustin M. Female genital mutilation/cutting in the UK: challenging the inconsistencies. European Journal of Women's Studies. 2010;17(1): 7-23.

115. Wax D. Female Genital Cutting, Sexuality, and Anti-FGC Advocacy. University of Nevada: Las Vegas. 2006. Available at https://www. academia.edu/1622829/Female_Genital_Cutting_Sexuality_ and_Anti-FGC_Advocacy.

116. Harryman GL. An analysis of the accuracy of the presentation of the human penis in anatomical source materials. In Flesh and Blood: Perspectives on the Problem of Circumcision in Contemporary Society, ed. Denniston GC, Hodges FM, Milos MF. New York: Kluwer Academic/Plenum Publishers. 2004;17-26.

117. Dekkers W. Routine (non-religious) neonatal circumcision and bodily integrity: a transatlantic dialogue. Kennedy Institute of Ethics Journal. 2009;19(2):125-146.

118. Earp BD. Autonomy is not the only game in town ... but it is the best game in town. Protecting Children's Rights in Europe: Recent Developments (Proceedings). 2013. Available at https://www.academia. edu/5790397/Autonomy_is_not_the_only_game_in_town_..._but_it_ is_the_best_game_in_town.

119. Hodges F. A short history of the institutionalization of involuntary sexual mutilation in the United States. In Sexual Mutilations, ed. Denniston GC, Hodges FM, Milos MF. New York: Springer. 1997;17-40.

120. Cohen SJ. Why aren't Jewish women circumcised? Gender and History. 1997;9(3):560-578.

121. Cohen SJ. Why Aren't Jewish Women Circumcised? Gender and Covenant in Judaism. Oakland: University of California Press. 2005.

122. Benatar D. Why do Jewish egalitarians not circumcise their daughters? Jewish Affairs. 2008; Chanukah:21-23.

123. Kimmel MS. The kindest un-cut. Tikkun. 2001;16(3):43-48. Available at http://www.cirp.org/pages/cultural/kimmel1/.

124. Aggleton P. "Just a snip"?: a social history of male circumcision. Reproductive Health Matters. 2007;15(29):15-21.

125. Lightfoot-Klein H. Prisoners of Ritual: An Odyssey into Female Genital Circumcision in Africa. Philadelphia: Haworth Press, Inc.; 1989.

126. Boyle GJ, Goldman R, Svoboda JS, Fernandez E. Male circumcision: pain, trauma and psychosexual sequelae. Journal of Health Psychology. 2002;7(3):329-343.

127. Darby R. A Surgical Temptation: The Demonization of the Foreskin and the Rise of Circumcision in Britain. Chicago: University of Chicago Press; 2005.

128. Glass M. Forced circumcision of men (abridged). Journal of Medical Ethics. 2013;40(8):567-571.

129. Ahlberg BM, Njoroge KM. 'Not men enough to rule!': politicization of ethnicities and forcible circumcision of Luo men during the postelection violence in Kenya. Ethnicity and Health. 2013;18(5): 454-468.

130. Spillius A. Indonesian Christians forced into Islamic faith. The Telegraph. February 5, 2001. Available at http://www.telegraph.co.uk/ news/worldnews/asia/indonesia/1321246/Indonesian-Christiansforced-into-Islamic-faith.html.

131. Plaskow J. Blaming Jews for inventing patriarchy. Lilith. 1980;7: 11-12.

132. Abdulcadir J, Margairaz C, Boulvain M, Irion O. Care of women with female genital mutilation/cutting. Swiss Medical Weekly. 2011;140:w13137.

133. Coleman DL. The Seattle compromise: multicultural sensitivity and Americanization. Duke Law Journal. 1998:717-783.

134. Merkel R, Putzke H. After Cologne: male circumcision and the law. Parental right, religious liberty or criminal assault? Journal of Medical Ethics. 2013;39(7):444-449.

135. Svoboda JS, Adler P, Van Howe RS. Circumcision is unethical and unlawful. Journal of Law, Medicine and Ethics, in press. 
136. Ludbrook R. The child's right to bodily integrity. Current Issues in Criminal Justice. 1995;7(2):123-132.

137. Lyons B. Male infant circumcision as a 'HIV vaccine'. Public Health Ethics. 2013;6(1):90-103.

138. Watson L. Unspeakable Mutilations: Circumcised Men Speak Out. Ashburton, NZ. 2014. Available at http://www.amazon.com/ Unspeakable-Mutilations-Circumcised-Men-Speak-ebook/dp/ B00L5FPF2C/ref=pd_ybh_1.

139. Jacobs AJ, Arora KS. Ritual male infant circumcision and human rights. American Journal of Bioethics. 2015;15(2):30-39.

140. Maslen H, Earp BD, Kadosh RC, Savulescu J. Brain stimulation for treatment and enhancement in children: an ethical analysis. Frontiers in Human Neuroscience. 2014;8(953): 1-5.

141. Svoboda JS. Promoting genital autonomy by exploring commonalities between male, female, intersex, and cosmetic female genital cutting. Global Discourse. 2013;3(2):237-255.

142. Plotkin S, Gerber JS, Offit PA. Vaccines and autism: a tale of shifting hypotheses. Clinical Infectious Diseases. 2009;48(4):456-461.

143. Darby R. The mysterious disappearance of the object of inquiry: Jacobs and Arora's defense of circumcision. American Journal of Bioethics. 2015;15(5):70-72.

144. Darby R. The child's right to an open future: is the principle applicable to non-therapeutic circumcision? Journal of Medical Ethics. 2013;39(7):463-468.
145. Hutson JM. Circumcision: a surgeon's perspective. Journal of Medical Ethics. 2004;30(3):238-240.

146. Darby R. Risks, benefits, complications and harms: Neglected factors in the current debate on non-therapeutic circumcision. Kennedy Institute of Ethics Journal. 2015;25(1):1-34.

147. Mason C. Exorcising excision: medico-legal issues arising from male and female genital surgery in Australia. Journal of Law and Medicine. 2001;9(1):58-67.

148. Earp BD, Sandberg A, Savulescu J. Brave new love: The threat of hightech "conversion" therapy and the bio-oppression of sexual minorities. AJOB Neuroscience. 2014;5(1):4-12.

149. Earp BD, Wudarczyk OA, Sandberg A, Savulescu J. If I could just stop loving you: Anti-love biotechnology and the ethics of a chemical breakup. American Journal of Bioethics. 2013;13(11):3-17.

150. Earp BD. Things I have learned (so far) about how to do practical ethics. Practical Ethics. University of Oxford. 2014. Available at http://blog. practicalethics.ox.ac.uk/2014/03/things-ive-learned-so-far-about-howto-do-practical-ethics/.

151. Earp BD. Prostitution, harm, and disability: Should only people with disabilities be allowed to pay for sex? Journal of Medical Ethics. 2015;E-letter. Available at https://www.academia.edu/13252176/ Prostitution_harm_and_disability_Should_only_people_with_ disabilities_be_allowed_to_pay_for_sex.
Medicolegal and Bioethics

\section{Publish your work in this journal}

Medicolegal and Bioethics is an international, peer-reviewed, open access journal exploring the application of law to medical and drug research and practice and the related ethical and moral considerations. The journal is characterized by the rapid reporting of reviews, case reports, guidelines and consensus statements, original research

\section{Dovepress}

and surveys. The manuscript management system is completely online and includes a very quick and fair peer-review system. Visit http://www.dovepress.com/testimonials.php to read real quotes from published authors. 